\title{
Exploring Art in Early Childhood Education
}

\author{
Danielle Twigg, Griffith University, Queensland, Australia \\ Susanne Garvis, Griffith University, Queensland, Australia
}

\begin{abstract}
In Australia and many other countries around the world, art education is considered a significant aspect of early childhood education. As Jalongo (1999) asserts, teachers who are not confident with their own artistic ability will negatively influence the art of their own students. Therefore, teachers of all stages of their careers need to be provided with training in relation to the art. Through ongoing professional development, teachers will develop basic skills to assist themselves in managing young children's artistic learning. In 2010, the authors completed a self-study of experiences from entering early years classrooms. Using reflective practice in a narrative approach, key themes emerged about skills and techniques needed in art education. This paper offers ways to support early childhood teachers to become more confident in their dealings with young children and their art experiences at school based on these findings. It provides guidance to teacher educators, schools and policy makers interested in improving quality Art education experiences for all students in early childhood education.
\end{abstract}

Keywords: Early Childhood, Arts, Teacher Education

\section{Introduction}

$\mathrm{E}$

ARLY CHILDHOOD EDUCATORS continue to struggle with ideas about the place of art in the curriculum and the most effective way to teach it. The quest for appropriate art education models has led educationalists to conduct research in an attempt to make sense of these issues. For example, the work of McArdle (1999) grapples with the concept of teaching art 'properly' (p. 102). O'Donnell (1996) investigates the value young children place on their art. Weier (2000) attempts to capture the meaning for children of art in museum settings. The work of these early childhood art education researchers represents only a few of the questions being addressed in current research. In general, early childhood educationalists address issues of aesthetics in relation to the display of artwork, but have yet to acknowledge young children's experiences surrounding the act of artwork display and its impact on them as individuals (Jalongo, 1999; Kim, Park \& Lee, 2001; Seefeldt, 2002). Jalongo (1999) maintains that children's artwork is a reflection of self-expression, meaning that teachers need to be cognizant of their responses to children's artistry.

In this article, the two researchers provide a critique of current practice in early childhood teacher education in classrooms based on a self-study of art education experiences. Using a narrative approach, key themes emerged regarding the practice of art in school. From the findings that emerged the researchers were able to offer suggestions to support early childhood teachers to become more confident in their dealings with young children and their art experiences at school. The researchers also offer guidance to teacher educators, schools and policy makers interested in improving quality art education experiences for all students in early childhood education. 


\section{Art Education in the Classroom}

Artistic learning and the best way to teach art to young children have been the subject of debate among many art educators and theorists, including Derham (1961), Eisner (1988), Gardner (2004), Lowenfeld \& Brittain (1970), Seefeldt (1999), Wright (2003b) and others from varying perspectives. The place of art in the curriculum and the best way of teaching art to young children are at the centre of this debate. Art education itself lacks a unified organisational structure which adds complication to the matter (Efland, 1990).

Approaches to early childhood art education and views of the 'child as artist' have been influenced by political, social, cultural, religious and economic views of childhood (Boone, 2008). Philosophical perspectives on early childhood pedagogy, including child development theory and the sociology of childhood also contribute to these understandings (James, Jenks \& Prout, 1998; McArdle \& Piscitelli, 2002; Pollock, 1983).

\section{Approaches to Early Childhood Art Education}

Art education practices vary widely, however three major approaches to teaching art in Western nations can be broadly categorised as progressive, discipline-based and contemporary (Efland, 1990). In response to the aforementioned debate, each approach offers very specific views of young children and the place of art within the wider school curriculum (McArdle, 1999; 2001).

The progressive approach to early childhood art education links artistic expression with children's natural development (Feldman, 1995). Influenced by Piaget's (1950) theory of child development, art educator Victor Lowenfeld's book, Creative and Mental Growth (1957) endorsed child-centred art education, articulating a stage theory of children's art development (Feldman, 1995). Lowenfeld and Brittain's (1970) approach is identified as laissezfaire, since it focuses on artistic expression through 'natural-unfolding' behaviours. Children's artwork is seen as free expression devoid of 'hidden meaning' (Levick, 1986). As Lowenfeld and Brittain (1970) assert "the art room should be a sanctuary against school regulations, where each youngster is free to be himself [sic] and to put down his [sic] feelings and emotions without censorship" (p. 108). The progressive approach remains evident in early childhood art education today.

Art education moved from a child-centred to a subject-centred focus, with the development of discipline-based art education (DBAE) by well-known American art educator Elliot Eisner (Efland, 1990). DBAE evolved from debates arising in the 1960s around the rationale for teaching art. Instead of teaching art as a form of creative self-expression as in the past, art educators promoted the idea of art as a discipline (Efland, 1990). Advocates of DBAE believed that art should be treated the same as all the other subjects in the curriculum. DBAE focused on the study of art history, criticism, and aesthetics, as well as with the production of artwork (Eisner, 1988). DBAE melded well with the emphasis on developmentally appropriate practice (DAP) promoted by early childhood educators and the National Association for the Education of Young Children (NAEYC) (Bredekamp, Copple \& NAEYC, 1997).

With the dawn of Postmodernism in the 1980s, art was promoted as social reconstruction and viewed as another way to transform society by encouraging diversity in art curriculum (Efland, 1990). Art educators began to build curriculum around concepts such as multiculturalism, feminism and popular culture (Efland, 1990). DBAE eventually gave way to CBAE 
(community-based art education) for art curriculum in schools (Efland, 1990), linking art to human and cultural experience (Congdon, Bolin, \& Blandy, 2001). Although there are several approaches to educating young children that are largely arts-focused, such as the Waldorf school model (Prescott, 1999), the most prominent of these in early childhood education is known as the 'Reggio Emilia approach' amongst early childhood professionals. The international model for early childhood education which evolved from the 'Reggio Emilia approach' (Edwards, Gandini \& Forman, 1993; Malaguzzi , Zini, Ceppi \& Reggio Children, 1998; Moore, 2006) acknowledges art as a language and recognises children's use of artistic media as integral to the cognitive/symbolic expression involved in learning. Other contemporary approaches include school-wide art projects (Hinde, 1999), community-based art (Aprill, 2003), the artist-in-residence model (Grant, 2003), children's responses to professional artists (Gibson \& McAllister, 2005), after-school programs for at-risk youth (Hogan, Munro, \& McLean, 2005), and museum learning (Piscitelli, 2001; Weier, 2000).

\section{Teacher Training}

Within early childhood education, art has been recognised for its contribution to the developing child (Bresler, 1992; McWhinnie, 1992; Spodek, 1993). Developmentalism supports the romantic notion that every child is an artist (James et al., 1998); Howard Gardner (2004) asserts the early childhood years are "a time when every child sparkles with artistry" (p. 86). Bowker and Sawyers (1988) argue that young children's capability for experiencing art has been underestimated. It has been suggested that early exposure to art is critically important and, if left unnurtured, may be difficult to recover (Eisner, 1988).

It is important to note the influence of training experiences and how they translate into early childhood curriculum and, in turn, into art education experiences for young children. Many pre-service teachers have had the opportunity to specialise in early childhood education (Roopnarine \& Johnson, 2004). Research has shown that teachers specifically trained in early childhood education provide higher quality care than those without such specialised training (Honig, 1995; Honig \& Hirallal, 1998).

The provision of creative opportunities for young children (e.g., dramatic play, art and crafts, and musical instruments) in early childhood education are plentiful, but initial training courses carry disproportionately small weighting for specific art studies (Hatfield, 2007; Kindler, 1997; Wright, 1991).

Early childhood educators typically do not have formal training in art education (Eisner, 1988; Eisner \& Day, 2004), but are encouraged to 'integrate' art into the core curricular areas. Kindler (1997) asserts that "teacher training has not prepared them adequately to assume initiatives in developing art curricula of such broad boundaries" (p. 346), and research suggests that teachers' lack of expertise in visual art teaching contributes to the gap between theory and practice (Fowler, 1989; Kindler, 1997; Piscitelli, 1993; Wright, 1991). Therefore, it is interesting to consider the ways in which early childhood teachers teach art education, even though it seems that they may not have been formally trained during pre-service coursework. What impact does their lack of formal training have on young children's experiences with the art? What assumptions do teachers make about children's art experiences in early childhood classrooms? On what basis do teachers make decisions about integrating the art into the early childhood curriculum? An investigation into possible answers to these questions follows. 


\section{Focus of Study}

This study focuses on providing a snapshot of current art practice in early childhood settings. By using a self-study based on recent personal experience in early childhood classrooms, it is possible to see areas of development in each of the classrooms visited.

\section{Reflective Practice}

Narrative inquiry, the research approach we employ in this self-study (Clandinin and Connelly, $2000 ; 2004)$ is considered a personal experience method in which story serves as both method and form. Drawing on a long history that includes Lane (1988) in geography, White (1988) in history, Scheffler (1997) in philosophy and Bruner (2002) and Coles (1989) in psychology, this self-study approach involves thinking about, viewing and contextualising our experiences as teacher educators for the art in the early years using Schwab's (1983) sense of the practical as our interpretive device. Thus, we examine the "autobiographical, historical, cultural and political and [take]...a thoughtful look at texts read, experiences had, people known and ideas considered" (Hamilton and Pinnegar, 1998, p.236).

For this study, the two researchers (one an experienced art educator and the other an experienced early childhood educator) on the Australian research team each wrote a short reflection on an experience which occurred whilst visiting an early childhood context. Each reflection spanned a page and included thoughts and ideas that were of concern to the research team. The research team then analysed each of the reflective texts for key themes regarding art education practice. Vignettes from the research text are presented below.

\section{Two Voices from the Lens of Teacher Educators}

Voice 1 is of a new early childhood lecturer. Previously she had worked in Australian early childhood and primary school settings teaching art education. Voice 1 has vast experience providing an integrated approach to the art in early childhood curriculums. Her voice reflects the current tensions towards art education:

I recently visited a pre-service teacher engaged in practical experience at an early childhood centre in one of the major city centres in Australia. The children in the centre came from various socio-cultural backgrounds and were between the ages of 3-5 years. While there, I noticed the children were engaged in phonics lessons. I asked the supervising teacher what the general plan was for each day. She responded "Well we really have to concentrate on the children learning literacy. We have moved away from a play-based curriculum to a formal teaching approach". I shivered on the insight. "What about the Art?" I ask. "Oh we did a little bit but not a lot. I don't really feel comfortable with the Art." I left the early childhood setting feeling uncomfortable. What were we valuing in early childhood education?

That night I began to mark folios from the early years students. I examined each of the curriculum plans and they began to have common themes. Where was the Art in the daily plans of early childhood centres? What if children wanted to do art? What about nurturing children's talents for certain categories of the art? 
The next day the question still puzzled me. What was wrong? Frustrated, I picked up the phone and dialled a friend at a local kindergarten. I began telling my tale. "But you don't understand", responded my friend. Her voice becomes stern. "There is no professional development to help these teachers see why the art are important. They have no-one to collaborate or network with. Most of them leave university not knowing how to teach the art. They need help and direction if you want them to teach the art", she stated. In one conversation, my question was answered. The problem was that some early childhood teachers did not have the knowledge or skills to teach the art.

Voice 2 is of another early career early childhood lecturer. Voice 2 has had a previous career as a government advisor in early childhood education. She has previously worked in early childhood settings in the United States and Australia. Her voice further reveals the tensions in early childhood art education:

The notion of displaying children's artwork has always been a fascination for me. As a young child, I recall the various feelings I had whenever I created art to share with my family and friends. As an early childhood teacher in an art-focused school in the USA, I became even more aware of the implications of displaying children's artwork. My own doctoral study, which focused on visual art in early childhood settings, revealed that children have very strong feelings about sharing their own visual artwork. For the study, a number of American children between the ages of 4-6 were interviewed about their lived experiences with the display of their own visual artwork. One of the children, six-year-old Georgia ${ }^{1}$, described an experience she had in relation to her artwork:

"One time, we were making a snowman and Lisa (pseudonym) actually it was Candace (pseudonym), we were both surprised about our snowmans [sic]. We put them in the drying rack to dry and they kind of got blue at the bottom. So we didn't really want it to hang up. We weren't happy with how it turned out. It wasn't our best and we didn't want everyone to see it. The teachers hung it up anyway and we felt kind of mad. We would have preferred that it would have turned out all white and be hung up on the wall, but instead the bottom turned kind of blue. We wished that the teachers would have asked us if we wanted it hung up. They never ask us. I think they should ask us sometimes. Most of the time I like how my art turns out, but I think kids should be able to decide whether or not their art is hung up because...just in case they don't want other people to see their artwork. You know - when it doesn't turn out the way they like it. I think art makes teachers feel very nice and, um, and they feel happy for us because we have fun doing it."

Georgia's description, as did many of the other children's descriptions, portrays her desire to have the ability to negotiate with adults regarding the display of her artwork. Certainly, no one wants their mistakes displayed on the wall for the world to see!

The experience Georgia describes is not uncommon in early childhood classrooms. As early childhood teachers, we hold dear the notion of young children's agency and competency; however it is difficult to see evidence of adult sensitivity in this description. As adults, we make assumptions about young children that sometimes need to be revisited. In this case,

\footnotetext{
${ }^{1}$ Pseudonym
} 
by simply talking to the child about his/her artwork, common understandings can lead to a restoration of children's rights in relation to the display of their own visual artwork.

After revisiting our own narratives as early childhood teacher educators, it is possible to see the key ideas we consider lacking in current early childhood education practice. Each idea is discussed below and provides future direction for early childhood art teacher education.

\section{Discussion and Offerings for the Future}

From the self-study, it became evident that early childhood teacher education requires further guidance for teachers to feel capable of teaching the art. Part of this involves being able to understand the basic techniques and skills for managing young children's art experiences. In particular, teachers need to understand sensitivity, identifying personal traits negotiation, collaboration with other and experience with ongoing professional development. These techniques and skills are now discussed, in turn.

\section{Sensitivity}

Adult sensitivity to young children's artwork has been identified as critical to children's self-esteem and interest in art (Derham, 1961; Wilson, Wilson \& Hurwitz, 1987). Australian art educator Francis Derham's (1961) work offers practical guidelines for providing materials to children and displaying student artwork, and presents evidence (e.g., school art contests and competitions) that insensitivity to a child's artistry may have a long-term impact on the child as both an artist and an individual. van Manen's (1991) work on the need for sensitivity on the part of adults when speaking to children about their own artwork has relevance, as well as the aforementioned doctoral study (Boone, 2008), have shown the significance of young children's experiences with the display of their own visual artwork.

By treating the practice of displaying children's artwork with less sensitivity than the practice of making art, adults diminish the emotional investment children make in their own visual artwork. The practice of displaying children's artwork must acknowledge both the child as artist and the creation itself, as opposed to simply performing a procedural function (e.g. automatically putting all artwork on display in order to represent all students equally, ignoring an individual child's request to opt out of a particular display of children's art). Early childhood teachers must be aware of their own positioning and involvement in children's artwork.

\section{Negotiation}

Literature on early childhood education in relation to children's rights (Bredekamp et al., 1997; Danby \& Farrell, 2004; Edwards et al., 1993; Mayall, 1994; NAEYC, 2001; United Nations, 1991) strongly supports the finding that children like to make choices about art. Recognition and respect for children's rights and experiences are components of many early childhood educational settings, including those influenced by the Reggio Emilia approach (Edwards et al., 1993; Malaguzzi et al., 1998). However, the act of facilitating children's decision-making requires negotiation and willingness on the part of the adult (Clark, McQuail \& Moss, 2003; Danby \& Farrell, 2004). 
Boone (2008) confirms that children are aware of the school art procedures developed by teachers. Children understand that there are 'rules' for the creation and display of art in school and this has an impact on their own artistic endeavours. As a result, it is important for early childhood educators (and other adults) to practice negotiating with young children in relation to art experiences - including display and other performance-based activities.

Lack of consideration on the part of adults to allow children to make decisions about the display of their own visual artwork appears to be the norm. Decisions about the display of children's visual artwork need to be made in consultation with the child-artist. The assumption that all children like all of their artwork displayed all of the time is false. Adults (including teachers, parents, researchers, carers and others) must begin to acknowledge children's rights in relation to the child as artist. The simple act of discussing the artwork and the proposed method of display with every child is a very powerful, yet subtle way to advocate for children's rights in relation to their own visual artwork.

\section{Identify Personal Talents}

Literature on multi-sensory learning and 'hands-on learning' experiences, in which children use artistic media, claim that these also provide a way for children to build conceptual understanding (Beck, 1967; Dewey, 1958; Wright, 1991). The exploratory nature of early childhood education allows children to make meaning through sensory involvement with objects and ideas (Dewey, 1958; Sternberg, 1999; Wright, 2003a). The complicated cognitive processes that occur throughout children's art making noted in Gardner's (2004) multiple intelligences theory were also evident in the study of young children's experiences with their own visual artwork being displayed (Boone, 2008).

In the early childhood classroom, teachers must acknowledge emotional investment and meaning of art work. The notion that children emotionally invest in art experiences and make thoughtful decisions throughout the creation process is supported by a selection of literature on art and educational theory (Boone, 2008; Gardner, 2004; James et al., 1998; Rousseau, 1762/1911; van Manen, 1991).

Seefeldt (2002) argues that children's artwork is indicative of their personal growth and development, so artwork displays should be designed thoughtfully and with care for the individual student. Children, unlike adults, did not appear to categorise art experiences in the same way as adults (Boone, 2008). The art they create can serve many purposes. For example, a piece of school art may be taken home and given to a parent as a gift. Or, art that is created in the home may be kept in a private place, as it was never intended to be shared with others but was made for the pure pleasure of the activity itself. Revisiting a piece of art made long ago can stir up an array of emotions from the child-artist ranging from laughter to sadness and anything in between. For young children, art has great meaning. The artwork of a child is an extension of him/her as a human being. At times, it can demonstrate a child's self-understanding or relationship to others, document new learning, or simply be an expression of the joy of making art!

\section{Networking and Collaboration}

Networking and collaboration is important for sustaining quality art education. Research suggests quality art education programs are characterised by strong partnerships between 
the schools and outside arts and community organisations (Bamford, 2006). One cost-effective approach has involved basing artists in schools and supporting sustained partnerships between education and arts organisation (Bamford, 2006). Accordingly, partnerships have the potential to reinvigorate teachers and creative professionals, and to build the confidence, creativity and enjoyment of all groups involved.

Early childhood art educators continue to struggle with ideas about the place of art in the curriculum and the most effective way to teach it. Children understand that there are 'rules' for the creation and display of art in school and this has an impact on their own artistic endeavours. Although linking art to the curriculum is strongly supported by the literature, neither the act of creating art for various purposes, nor the production of artwork at home, has been widely acknowledged in previous early childhood art education literature. Greater collaboration is necessary between schools, early childhood teachers and parents in encouraging and supporting art endeavours.

Guidance about encouraging arts practice in early childhood can be found in the Reggio Emilia approach. The Reggio Emilia approach (Edwards et al., 1993; Malaguzzi et al., 1998) provides guidelines for the creation and display of children's artwork based on their acknowledgment that children use art as a language, which assists adults in communicating with and documenting the learning of young children. Other research also supports teachers in the development of art-related procedures in relation to school art (Moore, 2006; Seefeldt, 2002). Seefeldt's (2002) work recognizes the different ways art can be displayed - formally or informally - and suggests informal art be displayed only at the teacher's discretion, while Moore's (2006) guidelines, which are based on the Reggio Emilia approach to display, are specific to the displaying of artwork for school art shows.

The Reggio Emilia approach also promotes networking and collaboration between the school and parents. By acknowledging that children use art as a form of communication, early childhood teachers can work with parents to provide suitable opportunities for art making in formal and informal learning environments.

\section{Professional Learning}

Although the progressive, discipline-based and contemporary approaches are the three major approaches to teaching art in Western nations, each approach embodies very specific views of young children and the place of art in the curriculum (McArdle, 1999, 2001). In early childhood classrooms, school art projects linked to units of study, or 'school art', provide a way of justifying the place of art in the curriculum (Efland, 1990; Wilson et al., 1987), which is different from art which children produce on their own, generally at home. The Reggio Emilia approach should also be acknowledged for its 'project approach' that integrates art into curriculum and also recognizes the spontaneous act of art creation in school (Edwards et al., 1993; Katz \& Chard, 2000; Malaguzzi et al., 1998).

Pedagogical methods (e.g., authentic learning, scaffolding, inquiry-based learning) are essential to teacher professional development, and this includes pedagogical methods regarding art education. The learning encounters of educators during workshops and conferences may be an important medium for changing understandings of early childhood art education. Provision of professional development for teachers is necessary and should enable them to become more confident in their dealings with young children and their art experiences at school. 
As mentioned previously, Jalongo (1999) acknowledges the impact of early childhood educators' own values and experiences in relation to their own artistry can influence and affect children's artistic learning. Professional learning experiences must therefore challenge negative beliefs that exist and support the development of positive beliefs towards the incorporation of arts education in the early childhood classroom. Further research supporting the long term development of positive arts beliefs, values and experiences of early childhood teachers is needed in early childhood education.

\section{Conclusion}

This self-study has shed light on current problems faced by early childhood teachers in Australia. By listening to two voices from the field, it was possible to identify areas of further need in teacher development. Future techniques and skills development is needed with sensitivity, negotiation, identifying personal talents and networking and collaboration. In particular, early childhood teachers require access to professional learning opportunities where teachers can learn how best to bring art education into the classroom.

Children make observations and judgments on their own art as well as the artwork of other children. These actions have the potential to influence children's own views of themselves and others as individuals. The existing literature reviewed does not appear to explicitly address children's views of their own art as well as the art of others. However, the literature implicitly supported the following: (1) children are sensitive to the aesthetic nature of their learning environment (Edwards et al., 1993; Katz \& Chard, 2000; Malaguzzi et al., 1998), (2) children make meaning through artistic experiences (Sternberg, 1999; Veale, 1992; Wright, 2003a), and (3) children are active participants and valuable informants of their own learning and social experiences (Danby \& Farrell, 2004; James et al., 1998; Mayall, 1994; Mead, 1943; Vygotsky, 1978). Again, van Manen's (1991) work on the need for sensitivity on the part of adults when speaking to children about their own artwork has relevance here.

This paper also raises questions about support structures that are available to early childhood teachers to support the delivery of art education in schools. In Australia, greater development of collaborative networks that encourage the development of communities of practice in art education is needed. Future research should be directed towards implementing and analysing the influence of such networks for teachers, such as an investigation of the learning journeys of early childhood teachers as they develop greater competence in teaching art. A holistic approach to improving early childhood teacher education in the arts may lead to higher quality art education experiences for students in early childhood education settings.

\section{References}

Aprill, A. (2003). Finding the thread of an interrupted conversation: The art, education, and community. Community Art Network Reading Room, 3.

Bamford, A. (2006). Global compendium on arts education research: What is quality arts education? Paper presented at Backing and Creativity: National Education and the Arts Symposium 2005. Canberra: Australia Arts Council.

Beck, J. (1967). How to raise a brighter child: The case for early learning. London: Souvenir Press. Boone, D.J. (2008). Young children's experience of visual displays of their artwork. Australian Art Education, 31 (2), 22-45. Carlton, VIC: Art Education Australia. 
Bowker, J. E., \& Sawyers, J. K. (1988). Influence of exposure on preschoolers' art preferences. Early Childhood Research Quarterly, 3, 107-115.

Bredekamp, S., Copple, C., \& NAEYC. (1997). Developmentally appropriate practice: In early childhood programs (2nd ed.). Washington, DC: National Association for the Education of Young Children.

Bresler, L. (1992). Visual art in primary grades: A portrait and analysis. Early Childhood Research Quarterly, 7, 397-414.

Bruner, J.S. (2002). Making stories: Law, Literature, Life. New York: Farrar, Straus \& Giroux.

Clandinin, D.J., \& Connelly, F.M. (2000). Narrative Inquiry: Experience and Story in Qualitative Research. San Francisco: Jossey-Bass.

Clark, A., McQuail, S., \& Moss, P. (2003). Exploring the field of listening to and consulting with young children (No. 445). London: Department for Education and Skills.

Coles, R. (1989). The Call of Stories: Teaching and the Moral Imagination. Boston: Houghton Mifflin.

Danby, S., \& Farrell, A. (2004). Accounting for young children's competence in educational research: New perspectives on research ethics. The Australian Educational Researcher, 31(3), 38-50.

Derham, F. (1961). Art for the child under seven (7th ed.). Watson, ACT: Australian Early Childhood Association.

Dewey, J. (1958). Art as experience. New York: Putnam.

Edwards, L.C., Gandini, L., \& Forman, G. E. (1993). The hundred languages of children: The Reggio Emilia approach to early childhood education. Norwood, NJ: Ablex Pub. Corp.

Efland, A. D. (1990). A history of art education: Intellectual and social currents in teaching the visual art. New York: Teachers College Press.

Efland, A. D. (2002). Art and cognition: Integrating the visual art in the curriculum. New York: Teachers College Press; National Art Education Association.

Eisner, E. W. (1988). The role of discipline-based art education in America's schools. Los Angeles: Getty Center for Education in the Art.

Eisner, E. W. (1996). Cognition and curriculum reconsidered (2nd ed.). London: Paul Chapman.

Eisner, E. W. (1998). Does experience in the art boost academic achievement? Art Education, 51(1), 7.

Eisner, E. W. (2000). Art education policy? Art Education Policy Review, 101(3), 4.

Eisner, E.W. \& Day, M. (Eds.) (2004). Handbook of research and policy in art education. Canada: University of British Columbia.

Feldman, E. B. (1995). The artist: A social history (2nd ed.). Englewood Cliffs, NJ: Prentice Hall.

Fowler, C. (1989). The art are essential to education. Educational Leadership, 47(3), 60-63.

Gardner, H. (2004). Frames of mind: The theory of multiple intelligences (20th anniversary ed.). New York: Basic Books.

Hamilton, M.L., \& Pinnegar, S. (1998). Conclusion: the value and promise of self-study. In M.L. Hamilton, T, Russell, L. Loughran, \& V, LaBoskey (Eds.). Reconceptualising Teaching Practice: Self-Study in Teacher Education. (pp. 235-246). London: Falmer.

Hatfield, T. A. (2007). Who teaches art? What is learned? Art Education Policy Review, 108(5), 7-8.

Hinde, J. (3 July 1999). Curriculum turns into an art form. The Australian, p. 1, from http://global.factiva.com

Honig, A. (1995). Choosing childcare for young children. In M. Bornstein (Ed.), Handbook for parenting (Vol. 4). Mahwah, NJ: Erlbaum.

Honig, A., \& Hirallal, A. (1998). Which counts more for excellence in childcare staff: Years in service, education level, or ECE coursework? Early Childhood Development and Care, 145, 31-46.

Jalongo, M. R. (1999). How we respond to the artistry of children: Ten barriers to overcome. Early Childhood Education Journal, 26(4), 205-208.

James, A., Jenks, C., \& Prout, A. (1998). Theorizing childhood. Cambridge, UK: Polity Press in association with Blackwell Publishers Ltd. 
Katz, L., \& Chard, S. C. (2000). Engaging children's minds: The project approach (2nd ed.). Stamford, CT: Ablex Pub. Corp.

Kindler, A. M. (1997). Child development in art. Reston, VA: National Art Education Association.

Kim, H., Park, E., \& Lee, J. (2001). “All done! Take it home.” Then into a trashcan?: Displaying and using children's art projects. Early Childhood Education Journal, 29(1), 41-50.

Lane, B.C. (1988). Landscapes of the Sacred: Geography and Narrative in American Spirituality. New York: Paulist Press.

Levick, M. (1986). Mommy, Daddy, look what I'm saying. New York: M. Evans \& Company, Inc.

Lowenfeld, V., \& Brittain, W. L. (1970). Creative and mental growth (5th ed.). New York: Macmillan (NY); Collier-Macmillan.

Malaguzzi, L., Zini, M., Ceppi, G., \& Reggio Children. (1998). Children, spaces, relations: Metaproject for an environment for young children. Reggio Emilia, Italy: Reggio Children.

Mayall, B. (1994). Children's childhoods: Observed and experienced. London: Falmer Press.

McArdle, F. (1999). Art and young children: Doing it 'properly'. Contemporary Issues in Early Childhood, 1(1), 101-104.

McArdle, F. (2001). Art in early childhood: The discourse of 'proper' teaching. Unpublished Doctoral Thesis, Queensland University of Technology Kelvin Grove, QLD.

McArdle, F., \& Piscitelli, B. (2002). Early childhood art education: A palimpsest. Australian Art Education, 25(1), 11-15.

McWhinnie, H. J. (1992). Art in early childhood education. In C. Seefeldt (Ed.), The early childhood curriculum: A review of current research (pp.264-285). New York: Teachers College Press.

Mead, M. (1943). Coming of age in Samoa: A study of adolescence and sex in primitive societies. Harmondsworth: Penguin.

Moore, K. B. (2006). How to create a school art show. Early Childhood Today, 20(5), 8-9.

NAEYC. (2001). NAEYC at 75, 1926-2001: Reflections on the past, challenges for the future. Washington, DC: National Association for the Education of Young Children.

O'Donnell, M. (1996). "You can let your mind run free when you've got art teachers": Young children's perceptions of art education. Unpublished Masters Thesis, Queensland University of Technology School of Early Childhood, Kelvin Grove, QLD.

Piaget, J. (1950). The psychology of intelligence. London: Routledge \& Paul.

Piscitelli, B. (1993). Children's artistic lives: The gap between rhetoric and reality. Paper presented at the Issues in Australian Childhood Conference, Brisbane, Queensland, Australia.

Piscitelli, B. (2001). Young children's interactive experiences in museums: Engaged, embodied and empowered learners. Curator, 44(3), 224-229.

Pollock, L. A. (1983). Forgotten children: Parent-child relations from 1500 to 1900. Cambridge: Cambridge University Press.

Prescott, J. (1999). A Day in the Life of the Rudolph Steiner School. Instructor, 109(4), 21-25.

Roopnarine, J. L., \& Johnson, J. E. (2004). Approaches to early childhood education (4th ed.). Upper Saddle River, NJ: Prentice Hall.

Rousseau, J-J. (1762/1911). Emile (On Education). London: Dent.

Scheffler, I. (1997). Symbolic Words: Art, Science, Language, Ritual. Cambridge: Cambridge University Press.

Schwab, J.J. (1983). The practical 4: something for curriculum professor to do. Curriculum Inquiry, $13(3), 239-265$.

Seefeldt, C. (2002). Creating rooms of wonder: Valuing and displaying children's work to enhance the learning process. Beltsville, MD: Gryphon House.

Spodek, B. (1993). Selecting activities in the arts for early childhood education. Art Education in Early Childhood, 94(6), 11-17.

Sternberg, R. J. (1999). Handbook of creativity. Cambridge, UK: Cambridge University Press.

United Nations. (1991). Convention on the Rights of the Child. New York: United Nations. 
van Manen, M. (1991). The tact of teaching: The meaning of pedagogical thoughtfulness. Albany, NY: State University of New York Press.

Veale, A. (1992). Making meaning with eyes and hands (Empirical Study). Adelaide: University of South Australia.

Vygotsky, L. S. (1978). Mind in society: The development of higher psychological processes. Cambridge, MA: Harvard University Press.

Weier, K. (2000). Lessons from an interactive exhibition: Defining conditions to support high quality experiences for young children. Unpublished Masters Thesis, Queensland University of Technology.

White, H. (1988). Historiography and historiophoty. American Historical Review, 93(5), 1193-1199.

Wilson, B., Wilson, M., \& Hurwitz, A. (1987). Teaching drawing from art. Worcester, MA: Davis Publications.

Wright, S. (1991). The art in early childhood. Brookvale, NSW: Prentice Hall.

Wright, S. (2003a). Children, meaning-making and the art. Frenchs Forest, NSW: Pearson Education.

Wright, S. (2003b). The art, young children, and learning. Boston: Allyn and Bacon.

\section{About the Authors}

Dr. Danielle Twigg

Dr. Danielle Twigg has recently been appointed as Lecturer to the School of Education and Professional Studies (Brisbane, Logan) following careers as an Early Years teacher and researcher in both Australia and North America. Danielle has worked as Senior Program Officer for the Office for Early Childhood Education and Care, Department of Education and Training (Queensland Government) on strategic initiatives in relation to achieving universal access to quality kindergarten program for all Queensland children.

\section{Susanne Garvis}

Susanne Garvis is a lecturer in early childhood education at Griffith University, Gold Coast. She teaches music education, child development and gifted education. Susanne is currently completing her $\mathrm{PhD}$. 